\title{
PENGARUH KONSEP KAIZEN (5S) TERHADAP PENINGKATAN DAYA SAING USAHA KECIL DAN MENENGAH (UKM)
}

\author{
Netty Laura.S ${ }^{1 *}$, Catarina Cori Pradnya Paramita ${ }^{2 * *}$ \\ Fakultas Ekonomi dan Bisnis, Universitas 17 Agustus 1945 Jakarta
}

\begin{abstract}
This study looks at the phenomenon of the sector of Small and Medium Enterprises (SMEs) have a very strategic and important role that can be reviewed from various aspects. It takes the right concept to improve SMEs by implementing the Kaizen Concept $(5 s)$ which is a concept already used by big companies. This research is conducted to know the effect of Kaizen Concept on Improving Competitiveness of SMEs. The study used primary data with the dissemination of research questionnaires. Respondents of this research are all SMEs in North Jakarta. The results of this study explain that Aspect Seiri (compact) (X1) has a significant influence on Competitiveness of SMEs (Y). Seiton (Rapi) (X2) has a significant effect on the competitiveness of SMEs in North Jakarta, Seiso Aspect (Resik) (X3) has a significant effect on SME Competitiveness (Y) in North Jakarta. Respondents perceive Seiso (Resik) that belongs quite high. Seiso contribution (Resik) to SME's Competitiveness is explained by 35.7\%. Seiketsu aspect (Rawat) (X4) gives a significant influence to SME Competitiveness (Y) in North Jakarta. This means that the better Seiketsu (Rawat) (X4) it will be good also Competitiveness of SMEs (Y) in North Jakarta. The Shitsuke (Rajin) aspect is not significant in influencing the Competitiveness of SMEs in North Jakarta. Simultaneously, Seiri variables, Seiton (Rapi), Seiso (Resik), Seiketsu (Rawat), Shitsuke (Rajin), show a positive and significant impact on SME Competitiveness.
\end{abstract}

Keywords: Kaizen (5s), Competitiveness, Small and Medium Enterprises (SMEs)

\begin{abstract}
ABSTRAK
Penelitian ini melihat fenomena sektor Usaha Kecil Menengah (UKM) memiliki peranan yang sangat stategis dan penting yang dapat ditinjau dari berbagai aspek. Dibutuhkan konsep yang tepat untuk meningkatkan UKM dengan menerapkan Konsep Kaizen $(5 s)$ yang merupakan konsep yang sudah digunakan oleh perusahaan-perusahaan besar. Penelitian ini dilakukan untuk mengetahui Pengaruh Konsep Kaizen Terhadap Peningkatan Daya Saing UKM. Penelitian menggunakan data primer dengan penyebaran kuisioner penelitian. Responden penelitian ini adalah seluruh UKM di Jakarta Utara. Hasil penelitian ini menjelaskan bahwa Aspek Seiri (ringkas) (X1) mempunyai pengaruh yang signifikan terhadap Daya Saing UKM (Y). Aspek Seiton (Rapi) (X2) berpengaruh yang signifikan terhadap Daya Saing (Y) UKM di Jakarta Utara, Aspek Seiso (Resik) (X3) memberikan pengaruh yang signifikan terhadap Daya Saing UKM (Y) di Jakarta Utara. Responden mempersepsikan Seiso (Resik) yang dimiliki tergolong tinggi. Kontribusi Seiso (Resik) terhadap Daya Saing UKM dijelaskan sebesar 35.7\%. Aspek Seiketsu (Rawat) (X4) memberikan pengaruh yang signifikan terhadap Daya Saing UKM (Y) di Jakarta Utara. Artinya semakin baik Seiketsu (Rawat) (X4) maka akan baik pula Daya Saing UKM (Y) di Jakarta Utara. Aspek Shitsuke (Rajin) tidak signifikan dalam memengaruhi Daya Saing UKM di Jakarta Utara. Secara simultan, variabel Seiri (Ringkas), Seiton (Rapi), Seiso (Resik), Seiketsu (Rawat), Shitsuke (Rajin), menunjukkan pengaruh yang positif dan signifikan terhadap Daya Saing UKM.
\end{abstract}

Kata Kunci: Kaizen (5s), Daya Saing, Usaha Kecil Menegah (UKM)

\footnotetext{
* email: ${ }^{1}$ netty.simbolon@uta45jakarta.ac.id

***email: 2 catarinacori.pp@gmail.com
} 


\section{LATAR BELAKANG}

Dalam proses pemulihan ekonomi Indonesia, sektor UKM memiliki peranan yang sangat stategis dan penting yang dapat ditinjau dari berbagai aspek. Pertama, jumlah industrinya yang besar dan terdapat dalam setiap sektor ekonomi. Berdasarkan data Badan Pusat Statistik (BPS), jumlah UKM tercatat 41,36 juta unit atau 99,9\% dari total unit usaha. Kedua, potensinya yang besar dalam penyerapan tenaga kerja. Setiap unit investasi pada sektor UKM dapat menciptakan lebih banyak kesempatan kerja jika dibandingkan dengan investasi yang sama pada usaha besar. Sektor UKM menyerap 76,55 juta tenaga kerja atau 99,5\% dari total angkatan kerja yang bekerja. Ketiga, kontribusi UKM dalam pembentukan PDB cukup signifikan yakni sebesar 55,3\% dari total PDB.

Kebijakan pemerintah dalam pengembangan UKM dalam jangka panjang bertujuan untuk meningkatkan potensi dan partisipasi aktif UKM dalam proses pembangunan nasional, khususnya dalam kegiatan ekonomi dalam rangka mewujudkan pemeratan pembangunan melalui perluasan lapangan kerja dan peningkatan pendapatan. Kinerja nyata yang dihadapi oleh sebagian besar usaha terutama Usaha Kecil, dan Menengah (UKM) di Indonesia yang paling menonjol adalah rendahnya tingkat produktivitas, rendahnya nilai tambah, dan rendahnya kualitas produk.

Meskipun diakui pula bahwa UKM menjadi lapangan kerja bagi sebagian besar pekerja di Indonesia, tetapi kontribusi dalam output nasional masih di kategorikan rendah. Hal ini dikarenakan UKM, khususnya usaha mikro dan sektor pertanian (yang banyak menyerap tenaga kerja) mempunyai produktivitas yang sangat rendah. Bila upah dijadikan produktivitas, upah rata-rata di usaha mikro dan kecil umumnya berada di bawah upah minimum. Hal ini akan berdampak pada kemampuan UKM Indonesia untuk bersaing dalam menghadapi pasar bebas MEA.

Banyak sekali tantangan yang harus dihadapi oleh UKM dalam rangka meningkatkan produknya baik dalam bentuk kualitasnya ataupun kuantitasnya. Tantangan ini bisa datang dari internal ataupun eksternal UKM sendiri. Faktor teknis internal yang menghambat UKM antara lain peralatan yang sederhana, pemborosan yang sering terjadi dalam proses produksi, kualitas dan motivasi pekerja yang minim, modal yang minim sehingga menyebabkan UKM sulit untuk meningkatkan produksinya baik secara kualitatif dan kuantitatif. Faktor eksternal yang menghambat UKM antara lain sarana dan prasarana yang tidak mendukung. Tingkat persaingan usaha (kompetitor) yang semakin ketat dan maju baik yang berasal dari dalam ataupun luar Indonesia.

Menurut kamus besar bahasa indonesia (KBBI), strategi diartikan sebagai ilmu dan seni menggunakan semua sumber daya bangsa untuk melaksanakan kebijaksanaan tertentu dalam perang dan damai. Sedangkan beberapa pengertian lain mengenai daya saing, yaitu:

1. Menurut Council of Competitiveness, Washington DC, pada tahun 2006, daya saing adalah kapasitas bangsa untuk menghadapi tantangan persaingan pasar internasional dan tetap menjaga atau meningkatkan pendapatan riil-nya.

2. Menurut European Commission pada tahun 1999, daya saing diartikan sebagai kemampuan menghasilkan produk barang dan jasa yang memenuhi pengujian internasional, dan dalam saat bersamaan juga dapat memelihara tingkat pendapatan yang tinggi dan berkelanjutan, atau kemampuan daerah menghasilkan tingkat pendapatan dan kesempatan kerja yang tinggi dengan tetap terbuka terhadap persaingan eksternal.

Permasalahan usaha kecil dan menengah (UKM) di Indonesia pada umunya relatif sama. Namun penentuan strategi untuk peningkatan daya saing, tetap harus meneliti UKM secara detail dan berkesinambungan agar tercipta suatu solusi dalam memenangkan persaingan yang ada. Oleh karena itu ada beberapa langkah yang bisa ditawarkan, agar UKM 
bisa menjaga dan memenangkan persaingan, yaitu:

1. Konsisten menjaga kualitas produk.

2. Tambahkan daya saing UKM melalui packaging produk yang menarik.

3. Berani bersaing dari segi harga.

4. Menjaga loyalitas konsumen

H. Nasution (2008) Sumber daya manusia (SDM) di dalam oraganisasi perusahaan merupakan kunci keberhasilan perusahaan, karena pada dasarnya sumber daya manusia yang merncang, memasang, mengopersaikan dan memelihara dari sistem integral dari perusahaan.

Langkah pertama untuk menang melalui manusia berdasarkan Kaizen adalah dengan menempatkan prioritas yang lebih tinggi pada sumber daya manusia dibandingkan sebelumnya. Enam bidang yang berharga untuk dipertimbangkan oleh organisasi dalam usaha meraih tujuan untuk menang melalui manusia dengan menggunakan Kaizen adalah (S. Cane, 2008)

1. Kebijaksanaan perekrutan dan seleksi yang melibatkan semua karyawan.

2. Peresmian program yang melibatkan perusahaan, departemen tim dan anggota secara individual.

3. Program pendidikan dan pengembangan yang terus berlangsung sehingga memberikan dorongan kepada semua karyawan untuk memiliki berbagai keahlian serta membantu mereka untuk sepenuhnya mewujudkan potensi.

4. Sistem penilaian yang mengembangkan manusia dan meningkatkan kerjasama diantara mereka.

5. Sistem penghargaan yang memotivasi dan tidak terpisah-pisah.

6. Program tanpa henti untuk peningkatan yang terus-menerus (Kaizen) yang meningkatkan setiap bidang pekerjaan dan melibatkan semua orang.

Dalam perspektif perkembangannya, UKM dapat diklasifikasikan menjadi 4 (empat) kelompok yaitu:

1. Livelihood Activities, merupakan UKM yang digunakan sebagai kesempatan kerja untuk mencari nafkah, yang lebih umum dikenal sebagai sektor informal. Contohnya adalah pedagang kaki lima.

2. Micro Enterprise, merupakan UKM yang memiliki sifat pengrajin tetapi belum memiliki sifat kewirausahaan.

3. Small Dynamic Enterprise, merupakan UKM yang telah memiliki jiwa kewirausahaan dan mampu menerima pekerjaan subkontrak dan ekspor.

4. Fast Moving Enterprise, merupakam UKM yang telah memiliki jiwa kewirausahaan dan akan melakukan transformasi menjadi Usaha Besar (UB).

Kaizen berasal dari kata kai yang berarti perubahan dan zenyang berarti menjadi lebih baik.Istilah ini mencakup pengertian perbaikan yang melibatkan semua aspek, baik manusianya, manajerialnya, dan juga mencakup permasalahan biaya (M.Imai, 1998). Filsafat Kaizen berpandangan bahwa cara hidup kita apakah itu kehidupan kerja atau kehidupan sosial maupun kehidupan rumah tangga hendaknya berfokus pada upaya perbaikan secara terus menerus. Konsep Kaizen menjelaskan mengapa perusahaan tak dapat tetap statis untuk jangka waktu lama di Jepang. Manajemen Barat, di sisi lain, memuja inovasi: perubahan besarbesaran melalui terobosan teknologi; konsep manajemen atau teknik produksi mutakhir. Kaizen adalah pendekatan dengan resiko dan biaya yang relatif rendah.

Manajemen harus belajar untuk menerapkan konsep dan sistem yang mendasar tertentu dalam rangka mewujudkan strategi Kaizen, yaitu (M. Imai, 1998).

1. Kaizen dan manajemen

2. Proses versus hasil

3. Siklus PDCA/SDCA

4. Mengutamakan kualitas

5. Berbicara dengan data

6. Proses berikut adalah konsumen

Semua orang di dalam perusahaan harus bekerja sama dalam mematuhi tiga aturan dasar penerapan Kaizen di tempat kerja, yaitu:(M. Imai, 1998) 
1. Penataan

2. Penghapusan

3. Standarisasi

Gemba dalam bahasa Jepang berarti tempat yang sebenarnya atau tempat dimana kejadian terjadi.Pendekatan baru yang kita sebut saja sebagai pendekatan berpusat gemba, dimana gemba bertanggung jawab tidak hanya terhadap produksi namun juga kualitas dan biaya, sedangkan staf membantu mereka dari pinggir. Kondisi yang dibutuhkan untuk tercapainya penerapan pendekatan terpusat gemba ada tiga, yaitu :

1. Manajemen gemba harus menerima tanggung jawab dalam mencapai kualitas, biaya, dan penyerahan (quality, cost, delivery/QDC).

2. Gemba harus diberi ruang gerak yang cukup untuk melakukan Kaizen.

3. Manajemen hendaknya menerapkan target untuk gemba, namun dia jugaharus mempertanggung jawabkan hasilnya.

Beberapa penelitian terdahulu dijelaskan sebagai berikut:

1. Andi Suranta Meliala,

Nazaruddin Matondang, dan Rahmi M

Sari menjelaskan Pemecahan permasalahan ini akan dilakukan dengan strategi Kaizen (5S) yang akan dipadukan dengan konsep Training within industry (TWI) dan konsep PCourse. Perbaikan ini akan menghasilkan strategi-strategi untuk peningkatan produktivitas kerja UKM secara keseluruhan dengan fokus utama adalah pekerja dan sistem kerjanya. Strategi ini diharapkan mampu membenahi kelemahan UKM sepatu yang ada, guna menghadapi ketatnya persaingan global yang akan datang.

2. Supiah Laelasari menjelaskan Metode 5S (seiri, seiton, seiso, seiketsu dan shitsuke) serta kualitas kerja karyawan pada perusahaan CV. Subur Jaya Honda Tasikmalaya termasuk dalam klasifikasi baik. Masing-masing variabel metode 5S (seiri, seiton, seiso, seiketsu dan shitsuke) secara parsial tidak berpengaruh signifikan terhadap kualitas kerja karyawan pada perusahaan $\mathrm{CV}$. Subur Jaya Honda Tasikmalaya. Secara simultan metode 5S (seiri, seiton, seiso, seiketsu dan shitsuke) juga tidak berpengaruh secara sigifikan terhadap kualitas kerja karyawan.

3. Muhamad Herman Indrajaya, Aziz Fathoni, dan Maria Magdalena Minarsih menjelaskan seiri dan seiton tidak memiliki pengaruh signifikan terhadap kinerja karyawan, sedangkan shiketsu mempunyai pengaruh positif dan signifikan terhadap kinerja karyawan. Kemudian melalui uji $\mathrm{F}$ dapat diketahui bahwa variabel seiri, seiton dan shiketsu secara simultan berpengaruh signifikan terhadap kinerja karyawan.angka Adjusted R square sebesar 0,397 menunjukkan bahwa kemampuan variabel seiri, seiton dan shiketsu dalam menjelaskan variabel kinerja karyawan adalah sebesar 39,7 \%. Dan masih ada 60,3\% variabel lain yang mempengaruhi variabel $\mathrm{Y}$.

4. Fitri Nuraini,dan Rieska Maharanidan Andrianto menjelaskan agar tidak kalah bersaing, pemerintah terdorong untuk membuat strategi dalam peningkatan daya saing di berbagai pasar persaingan baik pasar domestic maupun internasional. Kedua sektor tersebut tidak terlindas oleh ketatnya persaingan usaha dari negara lingkup ASEAN. Untuk mewujudkan hal tersebut, diperlukan sinergi yang berkelanjutan dari semua pihak terutama dari pemerintah dan pelaku sektor UMKM dan koperasi. Dan dengan munculnya era pasar bebas ASEAN (AEC) nantinya diwujudkan dengan melakukan integrasi ekonomi, yaitu aliran barang, jasa, investasi maupun tenaga kerja terdidik dan terlatih antar negara ASEAN untuk mewujudkan pembangunan di negara ASEAN. 
5. Ari Zaqi Al Faritsy dan Suseno menjelaskan Hasil Output dipengaruhi oleh faktor dalam proses produksi diantaranya defect dan waste. Proses penelitian dengan metodologi six sigma yaitu define, tahap ini mendefinisikan masalah dan aktivitas kerja, selanjutnya measure,tahap ini menghitung waktu baku, menghitung produktivitas awal dan membuat CVSM, kemudian analyze, tahap ini menganalisis penyebab terjadinya waste, dan menganalisis CVSM, dan terakhir improve, tahap ini membuat usulan proses produksi, aktivitas kerja, dan tata letak pabrik untuk meningkatkan produktivitas, menghitung produktivitas baru, dan membuat FVSM. Selain itu juga ada tahap perbaikan dengan 5S. Produktivitas kerja awal rangkaian rangka sebesar 1,56 sigma, setelah dilakukan perbaikan menjadi 1,99 sigma. Pada peta proses operasi saat ini ditemukan waktu transportasi $=37,5$ menit dan waktu delay $=305$ menit. Pada peta proses operasi usulan dihasilkan waktu transportasi $=16,25$ menit dan waktu delay $=70$ menit. Pada
CVSM waktu siklus $=4,71 \mathrm{jam}$, dan lead time $=38,86$ jam dengan total WIP $=299$ unit. Pada FVSM waktu siklus = 4,399 jam, dan lead time $=30,01$ jam dengan total WIP $=198$ unit.

6. Agus Supriyanto menjelaskan sikap kerja $5 \mathrm{~s}$ berpengaruh positif dan signifikan terhadap produktivitas.

7. M. Soleh menjelaskan orientasi kepemimpinan berpengaruh terhadap kemajuan UKM.

8. A. Kesumadinata D. Budiana menjelaskan UKM sepatu di Denpasar Barat, dimana dilakukan pengujian variabel tenaga kerja, harga, teknologi, dan modal yang berpengaruh besar pada perkembangan UKM. Hasil yang diperoleh bahwa tenaga kerja menjadi suatu faktor terbesar dalam memberi pengaruh untuk UKM.

\section{Rerangka Pemikiran}

Kerangka pemikiran adalah suatu diagram yang menjelaskan tentang proses penelitian dijalankan, sehingga hipotesis penelitian dapat dijawab. Kerangka pemikiran dalam penelitian ini dapat digambarkan sebagai berikut:

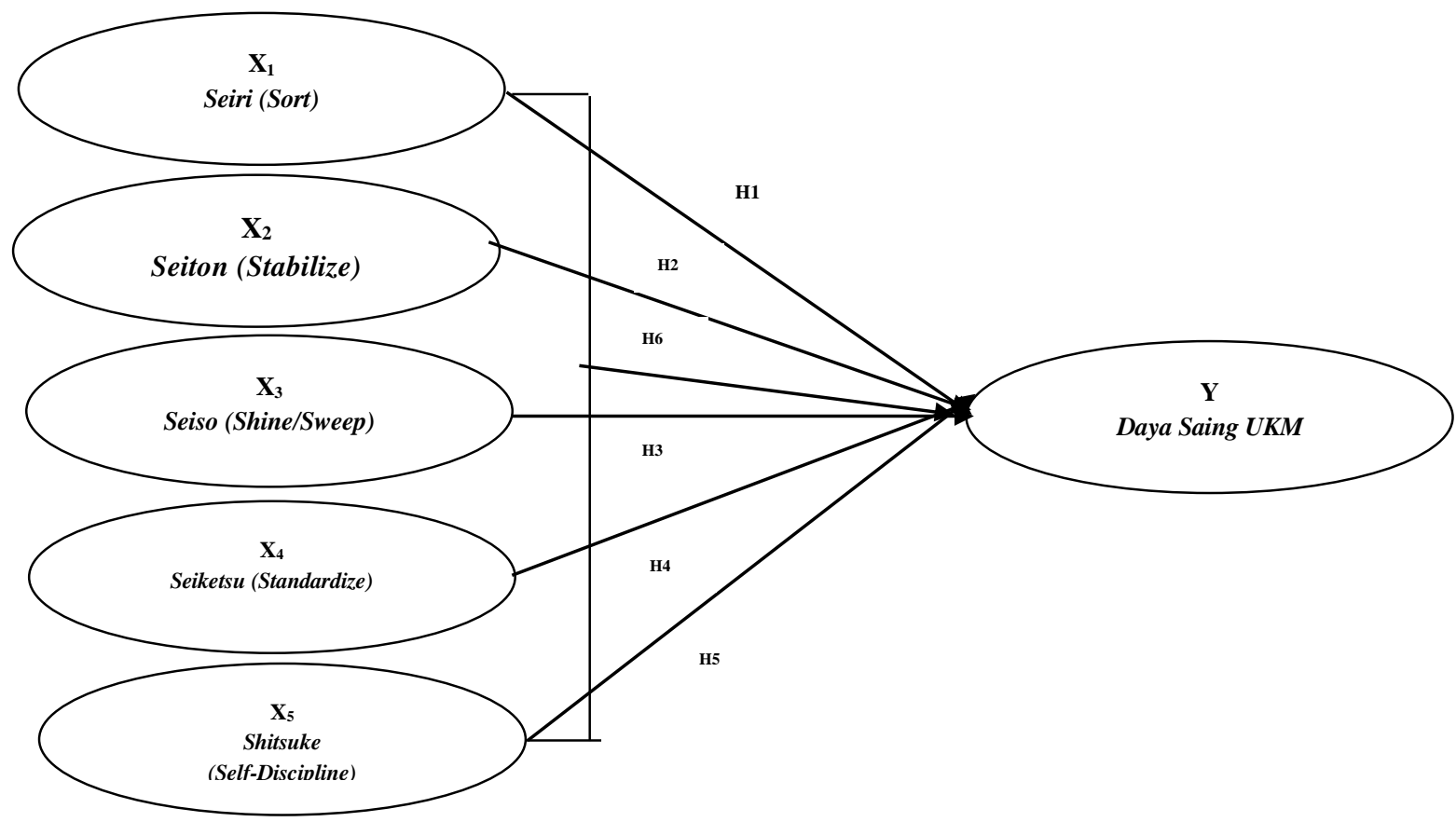

Gambar 1. Rerangka Pemikiran Sumber: Peneliti 


\section{METODE PENELITIAN}

Metode analisis yang pergunakan metode analisis regresi berganda. Dalam menganalisis data, langkah-langkah yang dipergunakan dalam analisis. Regresi berganda untuk data primer adalah sebagai berikut:

1. Rekap data dari kuisioner penelitian yang telah dikumpulkan sesuai dengan variable penelitian yang akan diteliti

2. Penyajian data dalam statistik deskriptif, untuk mengetahui gambara data penelitian, baik maksimum dan minimum data penelitian, maupun ratarata ataupun standar deviasinya.

3. Melakukan uji validitas. Suatu instrumen dikatakan valid bila instrumen tersebut memiliki kemampuan mengukur apa yang seharusnya diukur. Sebuah item atau pernyataan dikatakan valid jika mempunyai dukungan kuat terhadap skor total. Dengan kata lain item pernyataan dikatakan mempunyai validitas tinggi jika terdapat skor kesejajaran (korelasi tinggi) terhadap skor total item. Pengujian terhadap validitas item tersebut dilakukan melalui analisis faktor terhadap intrumen dengan cara mengkorelasikan jumlah skor item kuesioner dengan skor total. Selanjutnya dilakukan uji t dengan t-tabel untuk tingkat signifikasi 0,05dan derajat kebebasan $(\mathrm{dk})=\mathrm{n}-\mathrm{k}$.

4. Keputusan yang diambil adalah dengan membandingkan t-hitung dengan ttabel. Item pertanyaan dikatakan valid bila nilai t-hitung lebih besar dari pada t-tabel. Demikian sebaliknya, jika tidak valid bila nilai t-hitung lebih kecil dari nilai t-tabel.

5. Melakukan uji reliabilitas. Reliabilitas menunjukkan konsistensi dan stabilitas suatu skor dari suatu instrumen pengukur. Kriteria interpretasi realibilitasnya sebagai adalah cronbach alpha > 0,60 berarti reliabel, artinya instrumen yang bila digunakan beberapa kali untuk mengukur objek yang sama, akan menghasilkan data yang sama, dan jika cronbach alpha $<0,60$ berarti tidak reliabel, artinya instrumen yang bila digunakan beberapa kali untuk mengukur objek yang sama, akan menghasilkan data yang berbeda.

6. Uji parsial atau uji $\mathrm{t}$, yang bertujuan untuk mengetahui pengaruh secara parsial dari variable bebas terhadap variable terikat. Uji ini menggunakan bantuan SPSS (Statistic Program for Social Science). Tahapan ini sekaligus akan menjawab hipotesis penelitian yang parsial. Uji t atau t-test ini bertujuan untuk mengetahui besarnya pengaruh masing-masing variabel independen secara individual (parsial) terhadap variabel dependen. Hasil uji ini pada output SPSS dapat dilihat pada tabel Coefficients. Nilai dari uji t-test dapat dilihat dari p-value (pada kolom Sig.) pada masing-masing variabel independen, jika p-value lebih kecil dari level of significant yang ditentukan, atau t-hitung (pada kolom t) lebih besar dari t-tabel (dihitung dari two-tailed $\alpha=$ $5 \% \mathrm{df}=\mathrm{n}-\mathrm{k}$, k merupakan jumlah variabel independen dan $\mathrm{n}$ merupkan jumlah responden.

7. Uji simultan atau uji $F$, yang bertujuan unuk mengetahui pengaruh secara bersama-sama dari semua variable bebas terhadap variable terikat. Uji ini juga menggunakan bantuan SPSS (Statistic Program for Social Science). Tahapan ini sekaligus akan menjawab hipotesis penelitian yang simultan. Uji simultan dengan F-test ini bertujuan untuk mengetahui pengaruh bersama-sama variabel independen terhadap variabel dependen. Hasil F- test menunjukkan variabel independen secara bersamasama berpengaruh terhadap variabel dependen jika p-value (pada kolom sig.) lebih kecil dari level of significant yang 
ditentukan, atau $\mathrm{F}$ hitung (pada kolom F) lebih besar dari $F$ tabel. F-tabel dihitung dengan cara $\mathrm{df}=\mathrm{k}-1$, dan $\mathrm{df} 2=$ $\mathrm{n}-\mathrm{k}, \mathrm{k}$ adalah jumlah variabel dependen dan independen. Menghitung Koefisien Determinasi yang bertujuan untuk mengetahui berapa persen kemampuan variable bebas yang diuji dalam menjelaskan variable terikatnya.

8. Membuat persamaan regresi berganda yang bermanfaat untuk mengetahui besaran pengaruh terhadap variable terikat apabila variable bebas yang diuji mengalami perubahan naik ataupun perubahan turun.

\section{HASIL PENELITIAN DAN PEMBAHASAN}

\section{A. Pengujian Persyaratan Instrumen}

Untuk mendapatkan hasil dari tujuan penelitian ini, maka harus dilakukan uji analisis pernyataan apakah sudah valid dan reliabel. Kemudian variabel yang valid dan reliabel tersebut akan dilakukan analisi regresi linier berganda. Berdasarkan data yang telah diperoleh melalui angket/kuesioner, berikut hasil pengujian validitas

Tabel 1. Pengujian Validitas

\begin{tabular}{|c|c|c|c|}
\hline Pertanyaan & r hitung & $r$ table & Keterangan \\
\hline P1 & 0.564 & 0.19 & Valid \\
\hline $\mathrm{P} 2$ & 0.437 & 0.19 & Valid \\
\hline P3 & 0.672 & 0.19 & Valid \\
\hline $\mathrm{P} 4$ & 0.708 & 0.19 & Valid \\
\hline P5 & 0.598 & 0.19 & Valid \\
\hline $\mathrm{P} 6$ & 0.663 & 0.19 & Valid \\
\hline P7 & 0.704 & 0.19 & Valid \\
\hline P8 & 0.804 & 0.19 & Valid \\
\hline P9 & 0.654 & 0.19 & Valid \\
\hline $\mathrm{P} 10$ & 0.365 & 0.19 & Valid \\
\hline P11 & 0.750 & 0.19 & Valid \\
\hline P12 & 0.836 & 0.19 & Valid \\
\hline $\mathrm{P} 13$ & 0.874 & 0.19 & Valid \\
\hline P14 & 0.634 & 0.19 & Valid \\
\hline $\mathrm{P} 15$ & 0.642 & 0.19 & Valid \\
\hline P16 & 0.739 & 0.19 & Valid \\
\hline P17 & 0.754 & 0.19 & Valid \\
\hline P18 & 0.704 & 0.19 & Valid \\
\hline P19 & 0.714 & 0.19 & Valid \\
\hline P20 & 0.544 & 0.19 & Valid \\
\hline $\mathrm{P} 21$ & 0.625 & 0.19 & Valid \\
\hline $\mathrm{P} 22$ & 0.695 & 0.19 & Valid \\
\hline $\mathrm{P} 23$ & 0.635 & 0.19 & Valid \\
\hline $\mathrm{P} 24$ & 0.618 & 0.19 & Valid \\
\hline $\mathrm{P} 25$ & 0.627 & 0.19 & Valid \\
\hline P26 & 0.736 & 0.19 & Valid \\
\hline P28 & 0.706 & 0.19 & Valid \\
\hline
\end{tabular}

Sumber: diolah peneliti dengan SPSS 
Tabel 2. Pengujian Reliabilitas

Reliability Statistics

\begin{tabular}{|r|r|}
\hline Cronbach's Alpha & \multicolumn{1}{|c|}{ N of Items } \\
\hline .803 & 27 \\
\hline
\end{tabular}

Sumber: diolah peneliti dengan SPSS

Berdasarkan Tabel 5 dapat dilihat bahwa semua pernyataan berjumlah 28 pernyataan, dan diketahui masing-masing nilai r-hitung dan r-tabel dapat disimpulkan semua pernyataan adalah valid. Sedangkan nilai reliabilitasnya dengan menggunakan metode Cronbach Alpha (mengunakan software SPSS) berjumlah 0,803 dan r-tabel $(0,60)$ maka 0,869>0,60 sehingga pernyataan telah reliabel dan dapat digunakan kedalam analisis lebih lanjut dengan 27 pernyataan yang telah valid dan reliabel.

B. Pembahasan

1. Pengaruh Seiri (Ringkas) terhadap Daya Saing UKM (Y)

(X1)

Tabel 3. Analisis Regresi Berganda dengan Metode Enter $X_{1}, X_{2}, X_{3}$ dan $Y_{1}$

\begin{tabular}{|c|c|c|c|c|c|c|c|c|c|c|}
\hline \multicolumn{11}{|c|}{ Coefficients $^{\mathrm{a}}$} \\
\hline \multirow[b]{2}{*}{ Model } & $\begin{array}{l}\text { Unstand } \\
\text { Coeffi }\end{array}$ & $\begin{array}{l}\text { rdized } \\
\text { ients }\end{array}$ & $\begin{array}{l}\text { Standardiz } \\
\text { ed } \\
\text { Coefficien } \\
\text { ts }\end{array}$ & & & \multicolumn{3}{|c|}{ Correlations } & \multicolumn{2}{|c|}{$\begin{array}{c}\text { Collinearity } \\
\text { Statistics }\end{array}$} \\
\hline & B & $\begin{array}{l}\text { Std. } \\
\text { Error }\end{array}$ & Beta & $\mathrm{t}$ & Sig. & $\begin{array}{l}\text { Zero- } \\
\text { order }\end{array}$ & $\begin{array}{c}\text { Partia } \\
1\end{array}$ & Part & $\begin{array}{c}\text { Toleranc } \\
\mathrm{e}\end{array}$ & VIF \\
\hline 1 (Constant) & 7.584 & 2.883 & & 2.630 & .010 & & & & & \\
\hline $\mathrm{X} 1$ & .196 & .111 & .131 & 1.980 & .000 & .187 & .234 & .187 & .862 & 1.160 \\
\hline $\mathrm{X} 2$ & .207 & .112 & .195 & 2.005 & .000 & .190 & .247 & .263 & .859 & 1.164 \\
\hline $\mathrm{X} 3$ & .432 & .116 & .360 & 3.705 & .000 & .429 & .357 & .325 & .815 & 1.227 \\
\hline $\mathrm{X} 4$ & .406 & .122 & .323 & 3.333 & .001 & .403 & .325 & .292 & .817 & 1.224 \\
\hline $\mathrm{X} 5$ & -.020 & .099 & -.019 & -.203 & .840 & .152 & -.021 & -.018 & .846 & 1.181 \\
\hline
\end{tabular}

a. Dependent Variable:

Y

Sumber : Olah Data Primer dengan SPSS 
Berdasarkan Tabel 6 dapat dijelaskan pengaruh variabel Seiri (Ringkas) terhadap Daya Saing UKM di Jakarta Utara memiliki t hitung sebesar 1.980 lebih besar dari t tabel sebesar 1,96 dengan sig 0.000 lebih kecil dari probabilitas 0,05 sehingga memiliki berpengaruh signifikan dan positif. Besarnya pengaruh Seiri (Ringkas) terhadap Daya Saing UKM di Jakarta Utara terlihat pada kolom Correlation-partial yaitu sebesar 0,234 atau sebesar 23,4\%. Dilihat dari t hitung $1.980<\mathrm{t}$ tabel 1,96 yang berarti Seiri (Ringkas) berpengaruh signifikan terhadap Daya Saing. Hasil penelitian ini bertolak belakang dengan penelitian yang dilakukan oleh muhamad herman indrajaya, aziz fathoni, maria magdalena minarsih yang mengungkapkan bahwa seiri tidak memiliki pengaruh signifikan terhadap kinerja karyawan. namun sesuai dengan penelitian andi suranta meliala, nazaruddin matondang, rahmi $m$ sari Pertumbuhan ekonomi di Indonesia yang sangat signifikan ternyata tidak lepas dari peran dari usaha kecil dan menengah (UKM) yang menopang pertumbuhan ekspor dan impor, salah satu UKM yang bisa diunggulkan adalah UKM pembuatan sepatu.

\section{Pengaruh Seiton (Rapi) terhadap Daya Saing UKM (Y)}

(X2)

Berdasarkan Tabel 6 dapat dijelaskan pengaruh variabel Seiton (Rapi) terhadap Daya Saing UKM koefisien regresi variabel Seiton (Rapi) terhadap Daya Saing UKM adalah sebesar 0,195 dengan sig 0,00 lebih kecil dari probabilitas 0,05 sehingga memiliki berpengaruh signifikan dan positif. Besarnya pengaruh variabel Seiton (Rapi) terhadap Daya Saing UKM terlihat pada kolom Correlation-partial yaitu sebesar 0,247 atau sebesar 24,7\%. Dilihat dari t hitung $2.005>\mathrm{t}$ tabel 1.96 yang berarti Seiton (Rapi) berpengaruh signifikan terhadap Daya Saing. Berdasarkan hasil kuisioner, responden mempersepsikan Seiton (Rapi) yang dimiliki tergolong tinggi. Akan tetapi kenyataannya Seiton (Rapi) yang indikatornya dituangkan kedalam 5 pernyataan seperti Merancang metode penempatan untuk barang yang diperlukan, Menempatkan barang-barang yang diperlukan pada tempat yang telah dirancang dan disediakan, Tidak adanya pemberian label/identifikasi untuk mempermudah penggunaan dan pengembalian barang pada tempat yang telah ditentukan, Pemahaman tentang tempattempat yang ditentukan dalam proses produksi oleh pekerja sudah dilakukan, Tata letak penyimpanan-penyimpanan yang mempertimbangkan banyaknya barang dan seringnya pemakaian barang. Terutama dalam penyataan dalam Tidak adanya pemberian label/identifikasi untuk mempermudah penggunaan dan pengembalian barang pada tempat yang telah ditentukan perlu dilakukan perbaikan untuk meningkatkan mempermudah sistem kerja di UKM sehingga dapat bersaing dengan perusahaan besar.

\section{Pengaruh Seiso (Resik) (X3) terhadap Daya Saing UKM (Y)}

Besar hubungan yang Seiso (Resik) (X3) terhadap Daya Saing UKM (Y), dapat dilihat dari nilai koefisien $\mathrm{r}$ parsial sebesar 0.357. Hal ini menunjukkan bahwa kontribusi hubungan dari Seiso (Resik) terhadap Daya Saing UKM sebesar $35.7 \%$ jika variabel lainnya tetap. Selanjutnya untuk pengujian hipotesis digunakan uji $\mathrm{t}$ dan dari hasil perhitungan diperoleh t hitung sebesar 3.705 lebih besar dari t tabel sebesar 1.96 atau nilai sign $=0,000<\alpha=5 \% \quad(0,000<0,05)$ menyatakan $\mathrm{H}_{0}$ ditolak. Kesimpulannya bahwa terdapat pengaruh yang signifikan antara Seiso (Resik) terhadap Daya Saing UKM. Berdasarkan hasil kuisioner, responden mempersepsikan Seiso (Resik) yang dimiliki tergolong tinggi, Hal ini juga terlihat dari besarnya kontribusi Seiso (Resik). Hal ini juga terlihat dari besarnya kontribusi Seiso (Resik) yang paling besar menunjukkan terhadap Daya Saing UKM sebesar $35.7 \%$. 
4. Pengaruh Seiketsu (Standardize) (X4) terhadap Daya Saing UKM (Y)

Besar hubungan yang Seiketsu (Standardize)) (X3) terhadap Daya Saing UKM (Y), dapat dilihat dari nilai koefisien $r$ parsial sebesar 0.325 . Hal ini menunjukkan bahwa kontribusi hubungan dari Seiketsu (Standardize) terhadap Daya Saing UKM sebesar 32,5\% jika variabel lainnya tetap. Selanjutnya untuk pengujian hipotesis digunakan uji $\mathrm{t}$ dan dari hasil perhitungan diperoleh t hitung sebesar 3.333 lebih besar dari $\mathrm{t}$ tabel sebesar 1.96 atau nilai sign $=$ $0,001<\alpha=5 \%(0,001<0,05)$ menyatakan $\mathrm{H}_{0}$ ditolak. Kesimpulannya bahwa terdapat pengaruh yang signifikan antara Seiketsu (Standardize) terhadap Daya Saing UKM. Berdasarkan hasil kuisioner yang terdiri dari 4 pertanyaan yang terdiri dari Adanya penetapan prosedur pemeliharaan kebersihan, penempatan dan penataan barang sesuai standarisasi, Kurangnya komunikasi ke setiap karyawan yang berada di tempat/area kerja tentang prosedur pemeliharaan. Mempertahankan metode penempatan barang yang diperlukan maupun tidak diperlukan dari waktu ke waktu, Mempertahankan Kebersihan Lingkungan tempat kerja secara terus-menerus. Akan tetapi adanya penetapan prosedur pemeliharaan kebersihan, penempatan dan penataan barang sesuai standarisasi masih sangat kurang hal ini diakibatkan oleh masih dilakukannya penempatan dan penataan barang yang masih belum sesuai standarisasi oleh karena itu perlu dilakukan peningkatan dalam standarisasi yang tepat untuk penempatan dan penataan barang
5. Pengaruh Shitsuke (Rajin) (X5) terhadap Daya Saing UKM (Y)

Berdasarkan Tabel 6 dapat dijelaskan pengaruh variabel Shitsuke (Rajin) terhadap Daya Saing UKM koefisien regresi variabel Shitsuke (Rajin) terhadap Daya Saing UKM adalah sebesar -0.19 dengan sig 0,840 lebih besar dari probabilitas 0,05 sehingga tidak berpengaruh signifikan dan positif. Besarnya pengaruh variabel Shitsuke (Rajin) terhadap Daya Saing UKM terlihat pada kolom Correlation-partial yaitu sebesar -0.21 atau sebesar $-21 \%$. Dilihat dari t hitung $-0.203<\mathrm{t}$ tabel 1.96 yang berarti Shitsuke (Rajin) tidak berpengaruh signifikan terhadap Daya Saing UKM. Hal ini terjadi karena pekerja yang ada tidak melaui proses rekrutmen yang benar melainkan hanya melalui proses kekerabatan sehingga pekerja yang ada di UKM mayoritas masih keluarga sendiri yang tidak memiliki kemampuan dalam melakukan inovasi organisasi mengenai metode/konsep kerja yang diterapkan perusahaan. Sehingga sistem kerja yang terjadi masih belum professional sehingga sulit terjadi proses produksi secara konsisten dan berkesinambunga yang tentunya berdampak kepada Daya Saing UKM tersebut.

6. Pengaruh Seiri (Ringkas), Seiton (Rapi), Seiso (Resik), Seiketsu (Rawat), Shitsuke (Rajin), terhadap Daya Saing UKM (Y)

Uji hipotesis secara simultan yaitu untuk menguji pengaruh secara bersamasama variable bebas terhadap variabel terikat digunakan uji F. Berikut ini hasil uji regresi berganda: 
Tabel 4. Analisis Regresi Berganda dengan Metode Enter $X_{1}, X_{2}, X_{3}$ dan $Y_{1}$

\begin{tabular}{|ll|r|r|r|r|r|}
\hline \multicolumn{7}{|c|}{ ANOVA $^{\mathrm{b}}$} \\
\hline 1 & Sum of Squares & df & Mean Square & F & Sig. \\
\hline & Regression & 93.310 & 5 & 18.662 & 7.246 & $.000^{\mathrm{a}}$ \\
& & 242.080 & 94 & 2.575 & & \\
& Residual & 335.390 & 99 & & & \\
& Total & & & & & \\
\hline
\end{tabular}

a. Predictors: (Constant), X5, X4, X3, X2, X1

b. Dependent Variable: Y

Model Summary

\begin{tabular}{|c|c|c|c|c|c|c|c|c|c|}
\hline \multirow[b]{2}{*}{ Model } & \multirow[b]{2}{*}{$\mathrm{R}$} & \multirow[b]{2}{*}{$\begin{array}{c}\mathrm{R} \\
\text { Square }\end{array}$} & \multirow[b]{2}{*}{$\begin{array}{c}\text { Adjusted R } \\
\text { Square }\end{array}$} & \multirow{2}{*}{$\begin{array}{c}\text { Std. Error } \\
\text { of the } \\
\text { Estimate }\end{array}$} & \multicolumn{5}{|c|}{ Change Statistics } \\
\hline & & & & & $\begin{array}{l}\text { R Square } \\
\text { Change }\end{array}$ & $\begin{array}{c}\mathrm{F} \\
\text { Change }\end{array}$ & df1 & $\mathrm{df} 2$ & $\begin{array}{c}\text { Sig. F } \\
\text { Change }\end{array}$ \\
\hline 1 & $.527^{\mathrm{a}}$ & .278 & .240 & 1.60478 & .278 & 7.246 & 5 & 94 & .000 \\
\hline
\end{tabular}

a. Predictors: (Constant), X5, X4, X3, X2, X1

\section{Sumber : Olah Data Primer dengan SPSS}

Dari hasil perhitungan didapatkan nilai $\mathrm{F}$ hitung sebesar 7.246 (signifikansi $\mathrm{F}=$ 0,000). Jadi Fhitung $>$ Ftabel (7.246>2.31) atau Sig $\mathrm{F}<5 \%(0,000<0,05)$. Artinya bahwa secara bersama-sama variabel bebas yang terdiri dari Seiri (Ringkas), Seiton (Rapi), Seiso (Resik), Seiketsu (Rawat) Shitsuke (Rajin), berpengaruh signifikan terhadap Daya Saing UKM.

Untuk mengetahui besarnya sumbangan variabel bebas terhadap variabel terikat dapat dilihat dari koefisien determinasi $\left(\mathrm{R}^{2}\right)$. Berdasarkan tabel 7 dapat diketahui koefisien determinasi sebesar 0,240 atau $24,0 \%$. Artinya bahwa variabel Y dipengaruh sebesar 24,0 \% oleh Seiri (Ringkas), Seiton (Rapi), Seiso (Resik), Shitsuke (Rajin), Seiketsu (Rawat) sedangkan sisanya 76.0\% dipengaruhi oleh variabel lain di luar variabel bebas tersebut.

Berdasarkan hasil analisis pada Tabel 7 diatas bahwa koefisien regresi variabel Seiri
(Ringkas) sebesar 0,131, variabel Seiton (Rapi) sebesar 0,195, Seiso (Resik) sebesar 0,360, variable Seiketsu (Rawat) sebesar 0.323 dan variabel Shitsuke (Rajin) sebesar 0.19 Persamaan regresi yang dihasilkan adalah:

$Y=7.584+0.131 X_{1}+0,195 X_{2}+0,360 X_{3}+0,323 X_{4-}$ $0,19 X_{5}+e$

\section{SIMPULAN}

Berdasarkan hasil analisis penelitian dan pembahasan hasil, selanjutnya dapat peneliti kemukakan beberapa kesimpulan sebagai berikut ;

1. Aspek Seiri (ringkas) (X1) terbukti mempunyai pengaruh yang tidak signifikan terhadap Daya Saing UKM (Y)., hipotesis alternate diterima (Ha) dan hipotesis nol (Ho) ditolak.

2. Aspek Seiton (Rapi) (X2) dalam penelitian ini terbukti memberikan pengaruh yang signifikan terhadap Daya Saing (Y) UKM di Jakarta Utara, artinya 
semakin baik Aspek Seiton (Rapi) maka akan baik pula Daya Saing UKM di Jakarta Utara

3. Aspek Seiso (Resik) (X3) dalam penelitian ini terbukti memberikan pengaruh yang signifikan terhadap Daya Saing UKM (Y) di Jakarta Utara. Berdasarkan hasil kuisioner, responden mempersepsikan Seiso (Resik) yang dimiliki tergolong tinggi, Hal ini juga terlihat dari besarnya kontribusi Seiso (Resik) yang paling besar menunjukkan terhadap Daya Saing UKM sebesar $35.7 \%$.

4. Aspek Seiketsu (Rawat) (X4) dalam penelitian ini terbukti memberikan pengaruh yang signifikan terhadap Daya Saing UKM (Y) di Jakarta Utara. artinya semakin baik Seiketsu (Rawat) maka akan baik pula Daya Saing UKM (Y) di Jakarta Utara.

5. Aspek Shitsuke (Rajin) dalam penelitian ini terbukti tidak signifikan dalam mempengaruhi Daya Saing UKM di Jakarta Utara. Hal ini terjadi karena pekerja yang ada tidak melaui proses rekrutmen yang benar melainkan hanya melalui proses kekerabatan sehingga pekerja yang ada di UKM mayoritas masih keluarga sendiri yang tidak memiliki kemampuan dalam melakukan inovasi organisasi mengenai metode/konsep kerja yang diterapkan perusahaan.

6. Pengaruh Berdasarkan hasil penelitian dan uji statistic dari variabel Seiri (Ringkas), Seiton (Rapi), Seiso (Resik), Seiketsu (Rawat), Shitsuke (Rajin), secara simultan (bersama-sama) menunjukkan pengaruh yang positif dan signifikan terhadap Daya Saing UKM.

\section{SARAN}

Memperhatikan adanya beberapa keterbatasan seperti yang telah disampaikan maka bagi penelitian selanjutnya perlu memperhatikan beberapa saran berikut ini:

1. Aspek Shitsuke (Rajin) dalam penelitian ini terbukti tidak signifikan dalam mempengaruhi Daya Saing UKM di Jakarta Utara. Hal ini terjadi karena pekerja yang ada tidak melaui proses rekrutmen yang benar melainkan hanya melalui proses kekerabatan sehingga pekerja yang ada di UKM mayoritas masih keluarga sendiri yang tidak memiliki kemampuan dalam melakukan inovasi organisasi mengenai metode/konsep kerja yang diterapkan perusahaan.Oleh karena pemilik UKM hendaknya merevolusi sistem perekrutan pegawai hendaknya dilakukan secara professional dengan melihat kemampuan dan kemauan sehingga dapat melakukan segala metode/konsep kerja yang berlaku secara tepat.

2. Selain itu peneliti menyarankan kepada peneliti lain yang akan meneliti permasalahan yang sama dengan kata lain melanjutkan penelitian ini dengan memberikan pertanyaan yang berbeda mengingat penelitian KOnsep Kaizen terhadap Daya Saing UKM masih kurang

3. Untuk Suku Dinas Koperasi, Usaha Kecil Menengah dan Perdagangan memberikan penyuluhan tentang pentingnya Konsep Kaizen yang merupakan Konsep yang digunakan di Perusahaan Besar sehingga UKM juga dapat bersaing dengan Perusahaan Besar mengingat Kontribusi UKM untuk Perekonomian yang besar.

\section{DAFTAR PUSTAKA}

Agus Supriyanto. 2014. Pengaruh Sikap Kerja 5S (Seiri,Seiton, Seiso, Seiketsu, Shitsuke) Terhadap Produktivitas Kerja. Riset Manajemen dan Akuntansi. Vol.5, No.9.

Andi Suranta Meliala, Nazaruddin Matondang, Rahmi M Sari, Strategi Peningkatan Daya Saing Usah, Jurnal Optimasi Sistem Industri, April 2014, Vol. 13 No. 2.

Ari Zaqi Al Faritsy, Suseno, 2015. Peningkatan Produktivitas Perusahaan Dengan Menggunakan Metode Six 
Sigma, Lean Dan Kaizen. Jurnal Teknik Industri, Vol. X, No. 2.

Daito Apolo, 2011, Pencarian Ilmu Melalui Pendekatan Ontologi, Epistimologi, Aksiologi, Mitra Wacana Media.

Fitri Nuraini, Rieska Maharani, Andrianto. 2016. Prosiding Seminar Nasional Ekonomi dan Bisnis \& Call For Paper FEB UMSIDA.

H. Nasution, 2008.Proses Pengelolaan Sumber Daya Manusia, Medan: USU Press.

Info ukm.wordpress.com, diunggah tanggal 21 mei 2014 jam 15.00 WIB.

Kesumadinata dan D. Budiana, Hubungan faktor yang berpengaruh terhadap produksi kerajinan sepatu di kecamatan Denpasar Barat. Jurusan Ekonomi .

Muhamad Herman Indrajaya, Aziz Fathoni, Maria Magdalena Minarsih, 2016. Pengaruh Budaya Kaizen Terhadap Kinerja Karyawan Dengan Self Efficacy Sebagai Variabel Moderating (Study In Pt. Djarum Unit Skt Kradenan Kudus ). Journal Of Management, Volume 2 No.2.

M. Imai, 1998. Gemba Kaizen : Pendekatan Akal Sehat, Berbiaya Rendah pada Manajemen : Terj : Kristanto Jahja, Jakarta: Pustaka Binaman Pressindo).

M. Soleh, 2008. Analisis Strategi Inovasi Dan Dampaknya Terhadap Perusahaan (Studi Kasus : Ukm Manufaktur Di Kota Semarang), Program Studi Magister Manajemen, Program Pasca Sarjana. Universitas Dipenogoro, Semarang.

Supiah Laelasari. Pengaruh Metode 5S (Seiri, Seiton, Seiso, Seiketsu dan Shitsuke) Terhadap Kualitas Kerja Karyawan (Survey Pada Staf Karyawan Perusahaan CV. Subur Jaya Honda Tasikmalaya). Program Studi Manajemen Fakultas Ekonomi Universitas Siliwangi Tasikmalaya

S. Cane, 2008. Ahli bahasa: Martin, Widjogkongko, Kaizen Strategies For
Winning Through People. Batam: Interaksara.

Pembangunan Fakultas Ekonomi Universitas Udayana, Denpasar, 2011. S. Sinulingga, Metodologi Penelitian, Medan: USU Press, 2012. 